\title{
Investigation of the association of two candidate genes ( $H$-FABP and PSMC1) with growth and carcass traits in Qinchuan beef cattle from China
}

\author{
W. Liang, H.L. Zhang, Y. Liu, B.C. Lu, X. Liu, Q. Li and Y. Cao \\ College of Animal Science and Technology, Northwest A \& F University, \\ Yangling, Shaanxi, China \\ Corresponding author: H.L. Zhang \\ E-mail: zhh17461@nwsuaf.edu.cn
}

Genet. Mol. Res. 13 (1): 1876-1884 (2014)

Received January 15, 2013

Accepted August 14, 2013

Published March 17, 2014

DOI http://dx.doi.org/10.4238/2014.March.17.15

\begin{abstract}
Growth and carcass traits are economically important quality characteristics of beef cattle and are complex quantitative traits that are controlled by multiple genes. In this study, 2 candidate genes, $H-F A B P$ (encoding the heart fatty acid-binding protein) and PSMC1 (encoding the proteasome 26S subunit of ATPase 1) were investigated in Qinchuan beef cattle of China. PCR-SSCP and DNA sequencing methods were used to detect mutations in the $H$-FABP and PSMC1 genes in Qinchuan cattle, and a $\mathrm{T}>\mathrm{C}$ mutation in exon 1 of $H-F A B P$ and a $\mathrm{T}>\mathrm{C}$ mutation in exon 9 of $P S M C 1$ were identified. The association of these 2 single nucleotide polymorphisms with growth and carcass traits of Qinchuan cattle was analyzed. The $\mathrm{T}>\mathrm{C}$ mutation in $H-F A B P$ was significantly associated with body length and dressing percentage $(\mathrm{P}<0.05)$ and the $\mathrm{T}>\mathrm{C}$ mutation in $P S M C 1$ with body length and hip width $(\mathrm{P}<0.05)$, indicating that both of the 2 mutations in $H-F A B P$ and PSMC1 had effects on growth and carcass traits in the Qinchuan beef cattle breed. Thus, the results of our study suggest that the $H-F A B P$
\end{abstract}


and PSMC1 gene polymorphisms could be used as genetic markers in marker-assisted selection for improving Qinchuan beef cattle.

Key words: $H-F A B P$; PSMC1; Polymorphism; Association study; Qinchuan cattle

\section{INTRODUCTION}

Growth and carcass traits are economically important quality parameters of beef cattle. These traits are controlled by multiple genes such as $I N S I G, I G F 1$, and others (Andrade et al., 2008; Liu et al., 2012). The need for ongoing improvement of quantitative traits of beef cattle has spurred the development of molecular biotechnology methods such as marker-assisted selection, which has emerged as a promising strategy for genetic improvement of growth and carcass traits of beef cattle (Meuwissen and Goddard, 1996). Thus, the relationships between candidate genes and these traits are increasingly attracting more attention.

The heart fatty acid-binding protein $(H-F A B P)$ gene encodes a cytosolic protein that transports fatty acids from the cell membrane to other sites where 3-acyl-glyceride and phospholipids are synthesized and fatty acids are oxidized (Veerkamp and Maatman, 1995). The H-FABP gene has been mapped to chromosome 6 in the domestic pig (Sus domesticus) in which $H-F A B P$ is a QTL for fatness traits (Moon et al., 2007). The bovine H-FABP gene maps to chromosome 2 (Roy et al., 2003), and results from a previous study suggest that FABPs might affect the thickness traits of back fat in beef cattle (Cho et al., 2008).

PSMC1 (proteasome 26S subunit of ATPase 1) is a 26S proteasome-regulatory subunit 4 (S4) encoded by the $P S M C 1$ gene. The $26 \mathrm{~S}$ proteasome is a multicatalytic proteinase complex with a highly ordered structure. PMSC1 is part of a protein-degrading complex that cleaves peptides in an ATP/ubiquitin-dependent process in a nonlysosomal pathway and plays an important role in many regulatory pathways, including cell cycle regulation, differentiation, and apoptosis (Coux et al., 1996; Glickman and Ciechanover, 2002; Wu et al., 2004). Previous studies have reported that the PSMC1 gene affects the growth and carcass traits of beef cattle. Guo et al. (2008) identified a single nucleotide polymorphism (SNP) in a PSMC1 intron that was significantly associated with average daily food intake $(\mathrm{P}<0.01)$, average daily gain, finishing average daily gain, body length, ratio of feed to meat, back fat thickness, and loin-muscle area $(\mathrm{P}<0.05)$.

On the basis of the biological properties and the association studies of the two genes mentioned above, it is hypothesized that both $H-F A B P$ and $P S M C 1$ may play important roles in the growth and carcass traits in cattle. In this study, we chose the Qinchuan beef cattle breed for this investigation. We used PCR-SSCP and DNA sequencing methods to identify mutations in the H-FABP and PSMC1 genes in this cattle breed in order to identify associations between sequence variations in these two genes and growth and carcass traits, which will be of benefit for cattle breeding in China.

\section{MATERIAL AND METHODS}

\section{Animal source and preparation of DNA samples}

A total of 404 animals were randomly selected from the Qinchuan commercial breeds 
reared in Shaanxi Province, China. The animals were healthy and were $30 \pm 2$ months old at slaughter. In accordance with the criteria of GB/T17238-1998, "Cutting Standard of Fresh and Chilled Beef in China" (China Standard Publishing House), the growth traits (including withers height, body length, and hip width) and carcass traits (including slaughter weight, carcass weight, and dressing percentage) were measured. Used a venipuncture method for blood collection, approximately $15 \mathrm{~mL}$ blood was drawn from each animal. Heparin $(2 \%)$ was added to the blood samples and DNA extracted from these samples and stored at $-80^{\circ} \mathrm{C}$.

\section{Primers and PCR amplifications}

The primers used to amplify the $H-F A B P$ and $P S M C 1$ genes were designed according to the published bovine H-FABP (EMBL ENSBTAT 00000022375) and PSMC1 sequences (GenBank accession No. AC_000167.1). Sequences of the PCR fragments were compared to identify possible SNPs in exons of the 2 genes. The primer sequences, fragments size, and the annealing temperatures $(\mathrm{Tm})$ in the PCR are shown in Table 1.

\begin{tabular}{|c|c|c|c|c|}
\hline Amplified region & Primer & Primer sequence (5'-3') & Size (bp) & $\operatorname{Tm}\left({ }^{\circ} \mathrm{C}\right)$ \\
\hline \multirow[t]{2}{*}{ Exon 1} & $\mathrm{H} 1 \mathrm{~F}$ & TGCTGGTCCCAGAGTCCTTGT & 225 & 55 \\
\hline & $\mathrm{H} 1 \mathrm{R}$ & GGGCTAGAGAACTGCTCCGAT & & \\
\hline \multirow{2}{*}{ Exon 2} & $\mathrm{H} 2 \mathrm{~F}$ & TACCСТTCССТCTGCC & 253 & 56 \\
\hline & $\mathrm{H} 2 \mathrm{R}$ & GGTGACGCCCTATTCC & & \\
\hline \multirow{2}{*}{ Exon 3} & $\mathrm{H} 3 \mathrm{~F}$ & TACССТСТTTCCACAGTCC & 107 & 58 \\
\hline & $\mathrm{H} 3 \mathrm{R}$ & TCCCGTCAACCATTTCC & & \\
\hline \multirow{2}{*}{ Exon 4} & $\mathrm{H} 4 \mathrm{~F}$ & TCCAGACACTCACCCAT & 274 & 57 \\
\hline & $\mathrm{H} 4 \mathrm{R}$ & ATTGACCTCAGAGCACC & & \\
\hline \multirow[t]{2}{*}{ Exon 9} & PSMC1F & GAGAGGGAGATTCAGCGAAC & 509 & 56 \\
\hline & PSMC1R & TCTTGGTCTTTTCGTCGGG & & \\
\hline
\end{tabular}

PCR was performed in a $15-\mu \mathrm{L}$ volume containing the following ingredients: $0.6 \mu \mathrm{L}$ (approximately $60 \mathrm{ng}$ ) genomic DNA template, $0.3 \mu \mathrm{L} 10 \mathrm{pmol} / \mu \mathrm{L}$ of each primer, $7.5 \mu \mathrm{L} 2 \mathrm{X}$

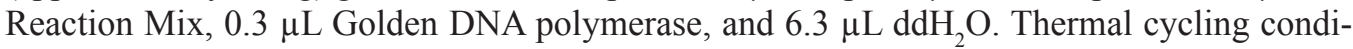
tions were 1 cycle at $95^{\circ} \mathrm{C}$ for $5 \mathrm{~min}$, followed by 36 cycles of $94^{\circ} \mathrm{C}$ for $30 \mathrm{~s}, 56^{\circ} \mathrm{C}$ (the optimal annealing temperature) for $40 \mathrm{~s}$, and $72^{\circ} \mathrm{C}$ for $40 \mathrm{~s}$; a final extension was performed at $72^{\circ} \mathrm{C}$ for $10 \mathrm{~min}$.

\section{Single-strand conformation polymorphism (SSCP) analysis}

The PCR-SSCP method was used to genotype the SNPs identified and for further analysis. A total volume of $12 \mu \mathrm{L}$ contained $4 \mu \mathrm{L}$ PCR product and $8 \mu \mathrm{L}$ denaturation buffer $(95 \%$ formamide; $10 \mathrm{mM}$ EDTA, $\mathrm{pH} 8.0,0.05 \%$ bromophenol blue) and was denatured at $98^{\circ} \mathrm{C}$ for $10 \mathrm{~min}$. The probes were then immediately chilled on ice and loaded onto $8 \%$ polyacrylamide gels containing freshly made $1 \mathrm{X}$ TBE buffer. The gels were run at $290 \mathrm{~V}$ for 5 min, followed by $200 \mathrm{~V}$ for $3 \mathrm{~h}$ and maintained at a low temperature (approximately $4^{\circ} \mathrm{C}$ ) by embedding them in ice. After electrophoresis, the gels with probes were silver stained and developed by using sodium hydroxide with formaldehyde. Individuals displaying different PCRSSCP patterns were sequenced with the ABI 3730 sequencer (ABI, Foster City, CA, USA). 


\section{Statistical analysis}

The linear model in the SPSS software (Version 16.0) was used to analyze the association between genotypes and traits in Qinchuan cattle. The linear model: $Y=\mu+A+G+E$, where $\mathrm{Y}=$ traits observed; $\mu=$ overall population mean; $\mathrm{A}=$ effect of the age; $\mathrm{G}=$ effect of the $\mathrm{SNP}$ marker genotype; and $\mathrm{E}=$ random error.

\section{RESULTS}

\section{PCR amplification and identification of SNPs in the H-FABP and PSMC1 genes}

In this study, $1 \mathrm{SNP}$ each was identified in the $H-F A B P$ gene and in the PSMC1 gene. The SNP in the $H-F A B P$ gene was a $\mathrm{T}>\mathrm{C}$ mutation at $69 \mathrm{bp}$ of exon 1 of the gene (T667C); the SNP introduced a missense mutation predicted to cause a change from a tyrosine to a histidine residue in the H-FABP protein. No mutations were detected in exons 2, 3, and 4 of $H$-FABP. The SNP in the PSMC1 gene was also a T $>$ C mutation in exon 9 at 972 bp of the PSMCl gene (T10852C) that was also a missense mutation. PCR-SSCP was used to genotype individual animals, and DNA sequencing methods were used to identify SNPs. The results of these analyses are shown in Figures 1 and 2.

A

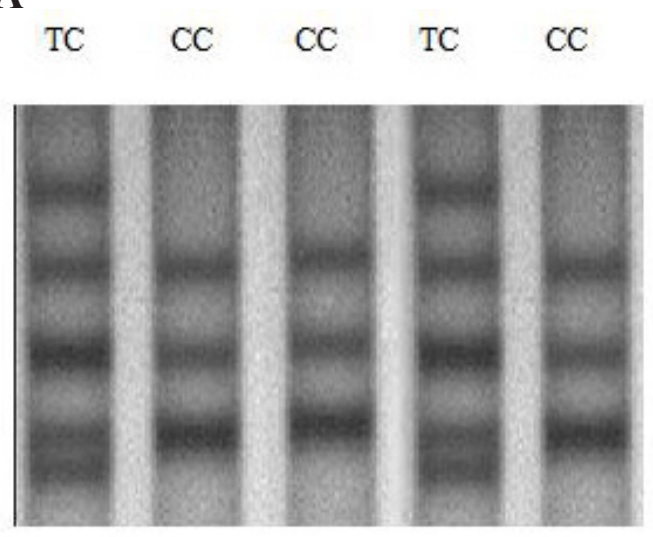

B

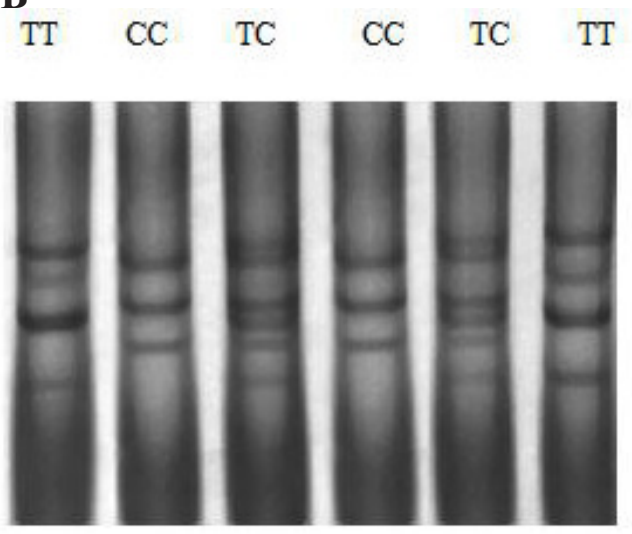

Figure 1. SSCP detection genotypes of products of $H-F A B P$ and $P S M C 1$ genes in Qinchuan. A. Different genotypes of the $P S M C 1$ gene. B. Different genotypes of the $H-F A B P$ gene.

\section{Analysis of the SNPs in H-FABP and PSMC1}

The allelic and genotypic frequencies and genetic diversity parameters [homozygosity, hemozygosity, effective number of alleles, and polymorphism information content (PIC)] of the 2 genes are shown in Table 2. As shown in the Table, in $H$-FABP, the frequency of the $\mathrm{T}$ allele (0.615) was greater than that of the $\mathrm{C}$ allele (0.385) and tests for Hardy-Weinberg distribution indicated that the $H$-FABP alleles were in extreme disequilibrium $(\mathrm{P}<0.01)$. The result 

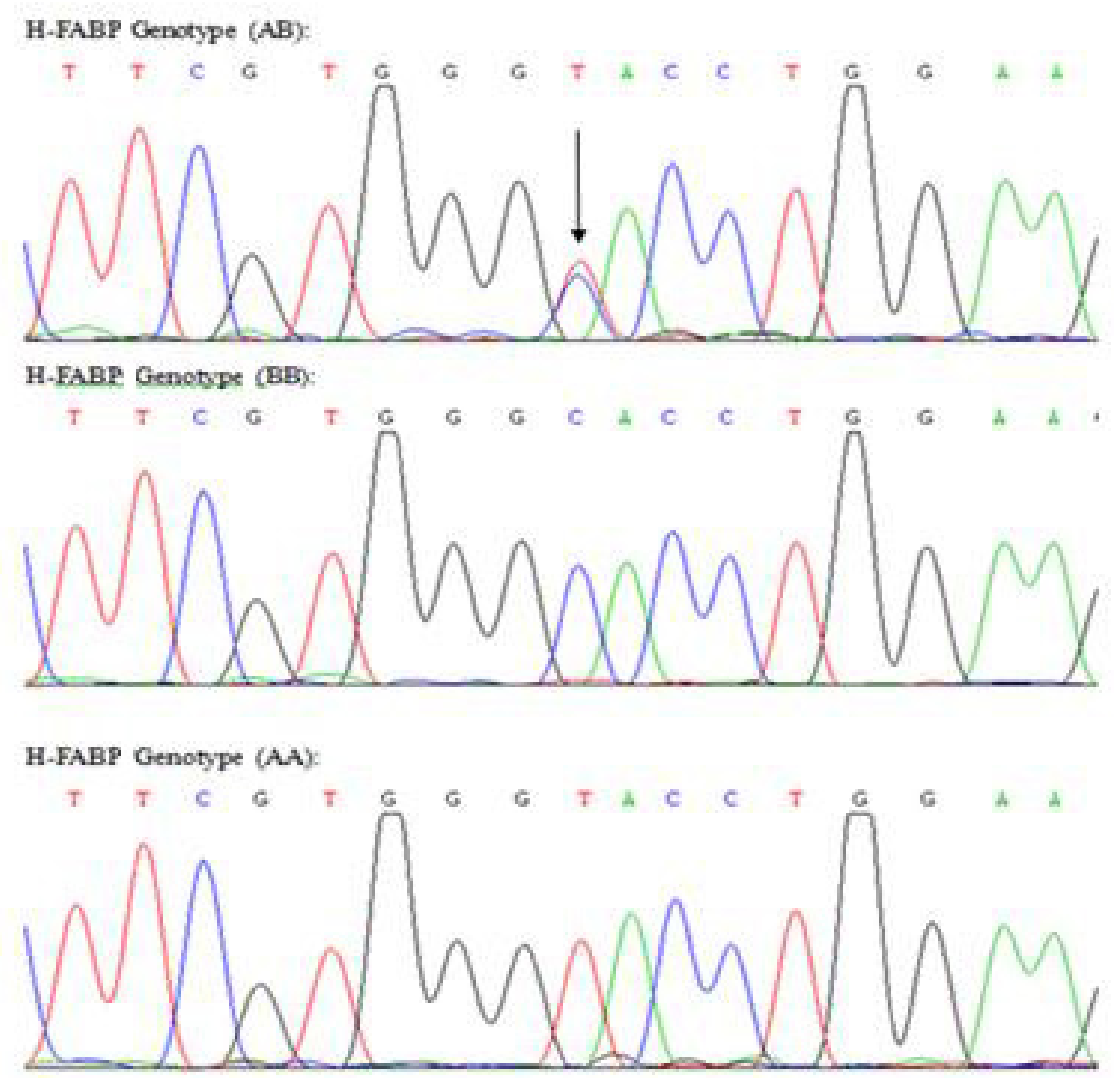

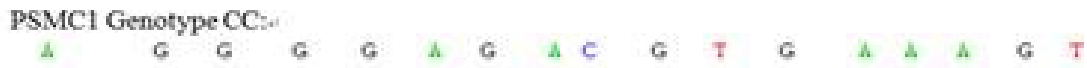

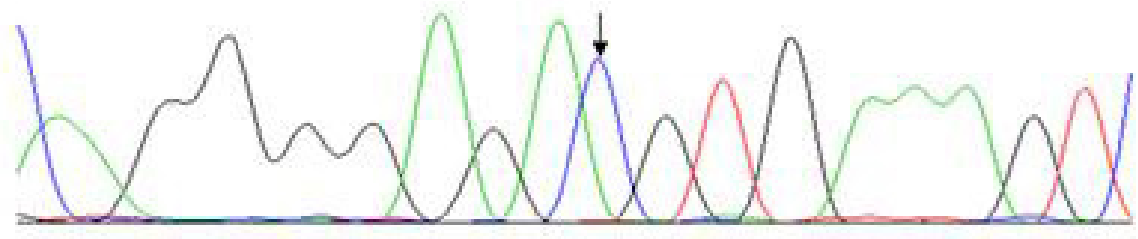

Genotype TC:

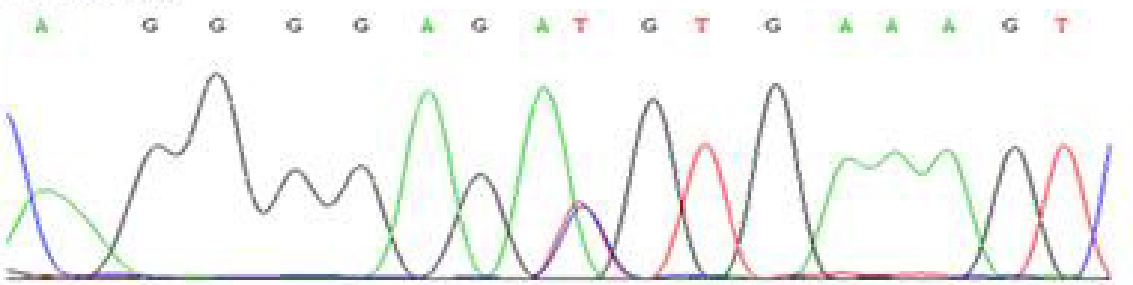

Figure 2. Sequencing results of different genotypes of $H-F A B P$ and $P S M C 1$ genes. 
of PIC eflected an intermediate genetic diversity of the Qinchuan bovine $H$-FABP gene in the population analyzed. Only CC and TC genotypes were identified in the PSMC1 gene, and the frequencies of the $\mathrm{C}$ allele was much greater than those of the $\mathrm{T}$ allele, and a Hardy-Weinberg extreme disequilibrium was detected $(\mathrm{P}<0.01)$. The PIC was in the $0.25-0.5$ interval, which reflected an intermediate genetic diversity in the Qinchuan cattle population analyzed for the PSMC1 gene. Next, we analyzed the association of the newly identified SNPs in the H-FABP and PSMC1 genes with growth traits (body height, body length, and hip width) and carcass traits (slaughter weight, carcass weight, and dressing percentage) in Qinchuan cattle (Table 3). As shown in Table 3, animals with the TT genotype of the $H$-FABP gene had longer bodies than those with the $\mathrm{CC}$ and $\mathrm{CT}$ genotypes $(\mathrm{P}<0.05)$; moreover, animals with the TC genotype had a lower dressing percentage than those with the $\mathrm{CC}$ and TT genotypes. In conclusion, animals with the TC genotype had better performance than those with CC and TT genotypes.

Table 2. Genotype and allele frequencies and genetic diversity parameters at H-FABP and PSMC1.

\begin{tabular}{|c|c|c|c|c|c|c|c|c|}
\hline Mutation & Genotypes & Frequencies & Allele frequencies & $\chi^{2}$ test & $H_{\mathrm{o}}$ & $H_{\mathrm{E}}$ & $N_{\mathrm{E}}$ & PIC \\
\hline \multirow{3}{*}{$\begin{array}{l}H-F A B P \\
\text { T667C }\end{array}$} & $\mathrm{CC}(\mathrm{N}=85)$ & 0.210 & $\mathrm{C}(0.385)$ & $\chi^{2}=13.613$ & 0.526 & 0.474 & 1.900 & 0.361 \\
\hline & $\mathrm{TC}(\mathrm{N}=141)$ & 0.350 & & $\mathrm{P}<0.01$ & & & & \\
\hline & $\mathrm{TT}(\mathrm{N}=178)$ & 0.440 & $\mathrm{~T}(0.615)$ & & & & & \\
\hline \multirow{2}{*}{$\begin{array}{l}P S M C 1 \\
\text { T10852C }\end{array}$} & $\mathrm{CC}(\mathrm{N}=224)$ & 0.555 & $\mathrm{C}(0.777)$ & $\chi^{2}=16.379$ & 0.654 & 0.346 & 1.529 & 0.286 \\
\hline & $\begin{array}{l}\mathrm{TC}(\mathrm{N}=180) \\
\mathrm{TT}(\mathrm{N}=0)\end{array}$ & $\begin{array}{l}0.445 \\
0\end{array}$ & & $\mathrm{P}<0.01$ & & & & \\
\hline
\end{tabular}

$\overline{H_{\mathrm{O}}}=$ observed homozygosity; $H_{\mathrm{E}}=$ expected heterozygosity; $N_{\mathrm{E}}=$ effective allele numbers; $\mathrm{PIC}=$ polymorphism information content.

Table 3. Association of the SNP with growth and carcass traits.

\begin{tabular}{|c|c|c|c|c|c|}
\hline \multirow[t]{2}{*}{ Traits } & \multicolumn{3}{|c|}{ Genotypes in $H$-FABP } & \multicolumn{2}{|c|}{ Genotypes in PSMC1 } \\
\hline & $\mathrm{CC}(\mathrm{N}=85)$ & $\mathrm{TC}(\mathrm{N}=141)$ & $\mathrm{TT}(\mathrm{N}=178)$ & $\mathrm{CC}(\mathrm{N}=224)$ & $\mathrm{TC}(\mathrm{N}=180)$ \\
\hline Body height (cm) & $139.60 \pm 2.51$ & $139.45 \pm 1.70$ & $139.92 \pm 1.62$ & $140.53 \pm 5.05$ & $139.57 \pm 5.20$ \\
\hline Body length $(\mathrm{cm})$ & $152.40 \pm 2.85^{\mathrm{b}}$ & $152.91 \pm 1.92^{\mathrm{b}}$ & $154.75 \pm 1.84^{\mathrm{a}}$ & $148.95 \pm 6.86^{b}$ & $152.80 \pm 5.13^{\mathrm{a}}$ \\
\hline Hip width $(\mathrm{cm})$ & $48.00 \pm 1.70$ & $47.50 \pm 1.15$ & $46.96 \pm 1.10$ & $46.73 \pm 3.95^{\mathrm{a}}$ & $44.36 \pm 4.30^{\mathrm{b}}$ \\
\hline Slaughter weight (kg) & $509.60 \pm 28.20$ & $502.91 \pm 19.02$ & $494.25 \pm 18.21$ & $489.17 \pm 51.56$ & $508.64 \pm 49.49$ \\
\hline Carcass weight (kg) & $289.68 \pm 16.46$ & $262.50 \pm 11.09$ & $277.27 \pm 10.62$ & $260.97 \pm 30.04$ & $281.67 \pm 27.36$ \\
\hline Dressing percentage $(\%)$ & $57.04 \pm 1.82^{\mathrm{a}}$ & $52.58 \pm 1.23^{\mathrm{b}}$ & $56.54 \pm 1.17^{\mathrm{a}}$ & $53.32 \pm 1.80$ & $55.45 \pm 3.09$ \\
\hline
\end{tabular}

Means within a row with different superscript letters differ significantly $(\mathrm{P}<0.05)$.

Polymorphisms in the PSMC1 gene also had effects on growth traits: animals with the TC genotype had longer bodies than those with the $\mathrm{CC}$ genotype $(\mathrm{P}<0.05)$, whereas the animals with the $\mathrm{CC}$ genotype had wider hip width than those with the TC genotype $(\mathrm{P}<$ 0.05). No significant differences between the CC and CT genotypes of the PSMC1 gene were detected for the carcass traits; however, the animals with the TC genotype tended to have improved carcass traits compared with animals with the CC genotype.

\section{DISCUSSION}

The H-FABP protein is believed to play an important role in the transport of fatty acid and in triglyceride accumulation in cells and to contribute to improved fat content (intra- 
muscular fat) of muscle. Gerbens et al. $(2000,2001)$ reported that a polymorphism in the $\mathrm{H}$ $F A B P$ gene from pig is associated with some carcass and growth traits, including body weight, back-fat thickness, and the intramuscular fat. Urban et al. (2002), studying the association of different $H-F A B P$ genotypes with fat and meat production of pigs, showed that $H-F A B P$ is an important candidate gene associated with carcass and growth traits of the animals. Zhou et al. (2005) investigating polymorphisms in the $H-F A B P$ gene in Luxi cattle and their association with meat-quality traits, found an SNP in intron 2 of $H$-FABP and that the homozygous BB genotype showed a highly significant positive effect on the Warner-Bratzler shear force in beef tenderness traits $(\mathrm{P}<0.05)$. Wang and Zan (2008) studied polymorphisms in exon 1 of the H-FABP gene in Qinchuan cattle and observed that these polymorphisms were also associated with such meat traits as crural girth, back-fat thickness, and marbling. Wang et al. (2011) further studied $H-F A B P$ gene polymorphisms and their association with growth traits in Qinchuan and related hybrid cattle and detected no statistically significant differences in growth traits among $H-F A B P$ genotypes in 3 cattle populations.

In this study, we used PCR-SSCP and DNA sequencing methods to detect the polymorphisms in all 4 exons of the $H$-FABP gene, and identified 1 missense mutation in exon 1 and noted that mutations were absent in the other 3 exons. The mutation in exon 1 of $H-F A B P$ was associated with growth and carcass traits in Qinchuan cattle as indicated by differences in body length and dressing percentage among animals with different genotypes; however, although no significant differences were detected among the different $H-F A B P$ genotypes in carcass traits, animals with the TC genotype tended to have better performance than those with the CC genotype, and the performance of animals with the CC genotype was better than that of the animals with the TT genotype. These results could inform the cattle breeding programs in China and contribute to improved marker-assisted selection for better performance in the cattle industry. Especially the TC genotype could be used as a molecular marker for superior growth and carcass yield and quality.

Previous research has focused mainly on the mapping of the PSMC1 gene and analyzing the structures and functions of the PSMC1 protein and other ATPases of the 26S proteasome. By using the fluorescence in situ hybridization method, Tanahashi et al. (1998) mapped the S4 (PSMC1) gene to the human chromosomes. Dubiel et al. (1992) reported that the cDNA sequence for subunit 4 ( $P S M C 1)$ had low sequence similarity to the ClpA gene in Escherichia coli (encoding the ATP-binding subunit of the E. coli protease $\mathrm{Clp}$ ). In addition, the protein sequence of the rat S4 (PSMC1) was predicted from an open reading frame encoding 440-amino acid residues with 4 conserved motifs (Gx4GKT, DEID, SAT, and H/QRxGRx2R), which were found in the central region of the rat ATPases and are characteristic features of a family of ATP-dependent RNA/DNA helicases (Makino et al., 1996). Ferrell et al. (2000) analyzed the regulatory subunit interactions of the 26S proteasome, and Richmond et al. (1997) analyzed the interactions between the different ATPases and discovered that these ATPases interact in the following pairs: Rpt2 (S4) binds to Rpt1 (S7), Rpt3 (S6b) binds to Rpt6 (S8), and Rpt5 (S6a) binds to Rpt4 (S10b). Gorbea et al. (2000) separated the 19S regulatory complex subunits by SDS-polyacrylamide gel electrophoresis, to identify the difference combinations of these subunits. The role of ATP hydrolysis in protein degradation at the level of the individual ATPase was analyzed by Rubin et al. (1998), whose results indicated that the ATPases are not functionally redundant and that they cooperate in the degradation of individual substrates.

In contrast, fewer studies have investigated polymorphisms in the PSMC1 gene. Guo et al. (2008) mapped the bovine PSMC1 gene onto BTA10 by using an radiation hybrid map- 
ping method and identified an SNP in the intron of the PSMC1 gene that is significantly associated with average daily feed intake $(\mathrm{P}<0.01)$, average daily gain, finishing average daily gain, body length, ratio of feed to meat, back-fat thickness, and loin-muscle area $(\mathrm{P}<0.05)$.

On the basis of these studies, we chose PSMC1 as a candidate gene and identified a novel SNP in its exon, and we were the first to associate a mutation in the PSMCl gene with growth and carcass traits in Qinchuan cattle. The results of our study indicated that the different PSMC1 genotypes had significant effects on the body length and hip width of this cattle breed, and the animals with the CT genotype tend to be better than those with the CC genotype. Therefore, the animals with the CT genotype could be used to develop new breeds of beef cattle in China, and the PSMC1 gene could be used as a candidate gene for bovine body measurements.

In conclusion, the SNP in the PSMC1 gene could be a potential candidate marker for marker-assisted selection in growth and carcass traits in Qinchuan cattle and could be used in cattle breeding and improvement in China.

\section{ACKNOWLEDGMENTS}

Research supported by the 12th "Five-Year" National Science and Technology Key Project (\#2011AA100307), the National "863" Program of China (\#2008AA101010), the "13115" Sci-Tech Innovation Program of Shaanxi Province (\#2008ZDKG-11), and the Undergraduate Innovative Test Program of Northwest A\&F University.

\section{REFERENCES}

Andrade PC, Grossi DA, Paz CC, Alencar MM, et al. (2008). Association of an insulin-like growth factor 1 gene microsatellite with phenotypic variation and estimated breeding values of growth traits in Canchim cattle. Anim. Genet. 39: 480-485.

Cho S, Park TS, Yoon DH, Cheong HS, et al. (2008). Identification of genetic polymorphisms in FABP3 and FABP4 and putative association with back fat thickness in Korean native cattle. BMB Rep. 41: 29-34.

Coux O, Tanaka K and Goldberg AL (1996). Structure and functions of the 20S and 26S proteasomes. Annu. Rev. Biochem. 65: 801-847.

Dubiel W, Ferrell K, Pratt G and Rechsteiner M (1992). Subunit 4 of the 26 S protease is a member of a novel eukaryotic ATPase family. J. Biol. Chem. 267: 22699-22702.

Ferrell K, Wilkinson CR, Dubiel W and Gordon C (2000). Regulatory subunit interactions of the 26S proteasome, a complex problem. Trends Biochem. Sci. 25: 83-88.

Gerbens F, de Koning DJ, Harders FL, Meuwissen TH, et al. (2000). The effect of adipocyte and heart fatty acid-binding protein genes on intramuscular fat and backfat content in Meishan crossbred pigs. J. Anim. Sci. 78: 552-559.

Gerbens F, Verburg FJ, Van Moerkerk HT, Engel B, et al. (2001). Associations of heart and adipocyte fatty acid-binding protein gene expression with intramuscular fat content in pigs. J. Anim. Sci. 79: 347-354.

Glickman MH and Ciechanover A (2002). The ubiquitin-proteasome proteolytic pathway: destruction for the sake of construction. Physiol. Rev. 82: 373-428.

Gorbea C, Taillandier D and Rechsteiner M (2000). Mapping subunit contacts in the regulatory complex of the $26 \mathrm{~S}$ proteasome. S2 and S5b form a tetramer with ATPase subunits S4 and S7. J. Biol. Chem. 275: 875-882.

Guo H, Liu WS, Takasuga A, Eyer K, et al. (2008). Mapping, expression, and association study of the bovine PSMC1 gene. Biochem. Genet. 46: 347-355.

Liu Y, Liu XL, He H and Gu YL (2012). Four SNPs of insulin-induced gene 1 associated with growth and carcass traits in Qinchuan cattle in China. Genet. Mol. Res. 11: 1209-1216.

Makino Y, Yogosawa S, Kanemaki M, Yoshida T, et al. (1996). Structures of the rat proteasomal ATPases: determination of highly conserved structural motifs and rules for their spacing. Biochem. Biophys. Res. Commun. 220: 1049-1054.

Meuwissen THE and Goddard ME (1996). The use of marker haplotypes in animal breeding schemes. Gene Sel. Evol. 28: $161-176$. 
Moon S, Shin HD, Cheong HS, Cho HY, et al. (2007). BcSNPdb: bovine coding region single nucleotide polymorphisms located proximal to quantitative trait loci. J. Biochem. Mol. Biol. 40: 95-99.

Richmond C, Gorbea C and Rechsteiner M (1997). Specific interactions between ATPase subunits of the $26 \mathrm{~S}$ protease. $J$. Biol. Chem. 272: 13403-13411.

Roy R, Calvo JH, Hayes H, Rodellar C, et al. (2003). Fine mapping of the bovine heart fatty acid-binding protein gene (FABP3) to BTA2q45 by fluorescence in situ hybridization and radiation hybrid mapping. Anim. Genet. 34: 466-467.

Rubin DM, Glickman MH, Larsen CN, Dhruvakumar S, et al. (1998). Active site mutants in the six regulatory particle ATPases reveal multiple roles for ATP in the proteasome. EMBO J. 17: 4909-4919.

Tanahashi N, Suzuki M, Fujiwara T, Takahashi E, et al. (1998). Chromosomal localization and immunological analysis of a family of human 26S proteasomal ATPases. Biochem. Biophys. Res. Commun. 243: 229-232.

Urban T, Mikolasova R, Kuciel J, Ernst M, et al. (2002). A study of associations of the H-FABP genotypes with fat and meat production of pigs. J. Appl. Genet. 43: 505-509.

Veerkamp JH and Maatman RG (1995). Cytoplasmic fatty acid-binding proteins: their structure and genes. Prog. Lipid Res. 34: 17-52.

Wang Z and Zan LS (2008). Study on SNP of H-FABP gene extron 1 and its association with some meat traits in Qinchuan cattle. J. Northwest A\&F Univ. 11: 11-15.

Wang S, Cai X, Xue K and Chen H (2011). Polymorphisms of MRF4 and H-FABP genes association with growth traits in Qinchuan cattle and related hybrids. Mol. Biol. Rep. 38: 1013-1020.

Wu X, Yu M, Liu B, Yerle M, et al. (2004). Mapping of three porcine 20S proteasome genes using the IMpRH panel. Cytogenet. Genome Res. 106: 142.

Zhou GL, Zhu Q, Guo SL and Wu YH (2005). Analysis on polymorphism of H-FABP gene in Luxi cattle and the relationships with meat quality traits. Acta Agric. Boreali-Occidentalis Sin. S823.81. 